\title{
Laundering women's history: A feminist critique of the social factory by Kylie Jarrett
}

\begin{abstract}
Studies of digital labour are closely connected to the concept of immaterial labour and how this has been critically interpreted by Autonomist Marxists who draw upon the concept of the social factory in explaining its wider impacts. The extension of labour and capitalist logics outside factory walls that constitutes the social factory is typically described as a novel feature of contemporary capitalism and particularly the digital economy. This paper critiques this assumption by utilising feminist theories of domestic work and examples of women's labour history. Using the particular case of Magdalene Laundries in the Irish Free State (1922-1937), it demonstrates that the social factory has a longer history than is usually presumed. It then describes the implications for analysis of digital labour that arise from rejecting the novelty of immaterial labour's incorporation into capitalism [1].
\end{abstract}

\section{Contents}

Introduction

The novelty of the social factory.

Social reproduction and the social factory.

Women in the Irish Free State's Social Factory

Magdalene Laundries as social factory.

Implications of the long history of the social factory

\section{Introduction}

Concepts drawn from the work of Michael Hardt and Antonio Negri, as well as other theorists associated with Autonomist Marxism, have been particularly influential in interrogating labour exploitation in the digital economy. These frameworks have provided a useful language for understanding the nature of work inside digital media industries, ranging from that of game developers, software coders and Web designers to the less valorised and less compensated work of beta testers or community managers. These same analytical tools have also been fundamental to conceptualising the activity of digital media users as a form of work, generating surplus value for increasingly monolithic media companies like Google and Facebook by supplying for free the content that animates these sites and simultaneously providing reams of data that can be sold to advertisers. What unites these two realms of work, and which identifies them as useful models for understanding broader socioeconomic trends, is the role played by labour based in the expenditure of energies such as cognition, affect and communicative competences and which produces goods that are similarly intangible: what is increasingly called immaterial labour.

Because it places this emphasis on the role of immaterial labour within and against contemporary capitalism, Autonomist Marxism has become the dominant lens for examining 
digital labour. However, as this paper will argue, the application of these ideas often relies on problematic androcentric assumptions about the nature of work and the historical role of immaterial labour within capitalism. In particular, this paper will focus on the idea of the social factory - the extension of labour and capitalist logics outside factory walls. This concept serves as a logical corollary of the centrality of immaterial labour in digital capitalism, for when work becomes entwined with subjectivity, affect, desire and thoughts, it becomes difficult to differentiate the working day from that which is leisure or self-making. The extension of capitalism's alienating logics in the development of the social factory forms the nucleus of the political critiques of immaterial labour contexts, such as digital labour.

Circulating with this concept, though, is the pervasive notion that there is something fundamentally new in the appropriation, exploitation and alienation of immaterial labour; that the social factory is an effect of post-Fordism, digitisation and/or financialisation of capital. This paper will firstly describe and then question this narrative, following this with a feminist critique of the tacit, foundational premises of the social factory concept using examples of feminised labour in the history of capitalism. As a particular example, it will then focus on the ways in which women's subjectivity, bodies and sexuality were incorporated into the founding socioeconomic logics of the Irish state through the mechanism of Magdalene Laundries. This feminist critique of the Irish social factory is thus not meant to discount the existence of capital's incorporation of the inalienable and the immaterial but to query the assumption of its novelty, thereby reframing the debate. It will conclude by exploring some of the implications of accepting that immaterial labour's incorporation into capital has a long history.

\section{The novelty of the social factory}

Autonomist Marxist theorists argue for the centrality of knowledge, social relations and communication - the troika of affective immaterial products - within contemporary capitalism. They describe a global economy where communication, digital systems and technical innovation have been placed at the core of the developed world's economic growth in ways that have decentred extractive and manufacturing industries and their associated industrialised, physical labour. Industries associated with symbol manipulation such as software development, marketing or media have taken on greater economic, cultural and social significance.

More importantly for the purposes of this paper, Autonomist Marxists also argue that the reorganisation of labour around immaterial products and processes extends the influence of the capitalist mode of accumulation, especially its practices of expropriation, exploitation and alienation. They contend that in immaterial capitalism, life processes such as cognition or affect that have historically been assumed as outside of capitalist logics become re-organised so that they reflect the logics of industrialised capital. In its most simple form, this occurs in the extension of the working day when, for example, a work-related idea, image or concept "comes to you not only in the office but also in the shower or in your dreams" [2]. Aided by mobile digital devices that render it difficult to assess when the workday ends (Gregg, 2011), contemporary capitalism invades our whole day with demands on our labour-power. Autonomist Marxists also point to the direct involvement of immaterial activity and goods, such as affect and care, into the economic calculations of capital. In contemporary digital capitalism, personal, social and leisure activities can be mined as data, captured in economic calculation as brand value, or be factored into share prices in the form of a corporation's human capital (Gorz, 2010).

In such contexts, the most valuable labour-power is no longer that instantiated in the labouring body, but is instead that emerging amongst and within the social subjects of capitalism.

Successful software, for instance, is not only the product of a single actor pressing the keys on a computer keyboard, but the amalgamation of a range of tacit or explicit knowledges instantiated in various forms, communicated between individuals and bearing the traces of previous iterations and understandings. Cooperative social relationships, interpersonal communication and/or affective intensities both inside and outside the workplace all become "the fixed capital 
whose combination with live labor makes that live labor productive" [3] . To contribute to this value creation, workers are encouraged/required to incorporate economic logics into their identities and to make the production and performance of that identity a core aspect of work (Gorz, 2010; Illouz, 2007; Rose, 1999). Virno suggests that the "permanent mutability of life enters the productive process by way of "job description" [4] in which the flexibility, opportunism and willingness to absorb contexts of precariousness that are required of a contemporary productive workforce are integrated into the socialisation of all subjects.

Incorporation of such labour into capital in both traditional leisure and paid work contexts blurs the boundary between processes of social being and industrialisation. As Nick Dyer-Witheford summarises, the "world of the socialized worker is thus one where capital suffuses the entire form of life" [ $[5]$. This intermeshing of sociality and the dictates of capital is mobilised in Autonomist Marxist thinking as 'the social factory'. This concept, attributed to Mario Tronti (1973), explains a context that moves beyond what Marx describes as the 'formal subsumption' of life - in which fundamentally unaltered labour and life processes contribute to capitalist accumulation — to a context of 'real subsumption' — where these same processes are reformed so that they actively support the capitalist mode of production. In doing so, life processes are considered to become directly productive and the social factory comes into being. The social factory is thus associated with an extensification of the expropriating and alienating effects of capitalist accumulation and with a system of control that permeates the entire social fabric, even to the core of individual subjectivity. Digital labour, particularly in the form of user exploitation, is one of the most overt instances of this phenomenon.

The blurring of boundaries between activity that can be appropriated by capital and that which is 'life', however, is often represented as a novel experience emerging from relatively recent changes in the mode of accumulation. For instance, Antonio Negri insists that it is in advanced capitalism that "we have seen how work processes have shifted from the factory to the society thereby setting in motion a truly complex machine" []. This phrase is also cited by Tiziana Terranova (2000) in her influential argument about the role of free labour in the digital economy. Her later revision to that article also refers to "a new kind of exploitation - that which concerns the immaterial commons of cultural and technical production" [7]. Maurizio Lazzarato (1996) specifically associates immaterial labour and the social factory with post-Fordist, post-industrial economies and in particular with the 'great transformation' of the 1970s which diminished the necessity of manual labour in the developed world through processes of automation and offshore production. Similarly, Franco 'Bifo' Berardi describes how throughout "the history of capitalism the body was disciplined and put to work while the soul was left on hold, unoccupied and neglected". This, he says, was the situation until the post-industrial context of the "last decades of the twentieth-century" where now even the soul is in the service of capital [8]. McKenzie Wark also notes the "wake-up call for educated people in the overdeveloped world" that "what we do has finally been proletarianized". This is because what "were formerly qualities of private, affective and intimate life are now the kinds of labor that can be commodified" [9].

Assertions of the novelty of the social factory that have crept into understandings of immaterial labour, and subsequently into many studies of digital labour, imply that until recently there have been spaces unnecessary to capitalist accumulation and which have, therefore, been outside of its logics. It also suggests that it is only a contemporary phenomenon that immaterial labour has been incorporated into the machinery of capitalism, or captured by its measures. There is the implication that through recent technological change, but particularly digitisation, we have moved into an epoch with a new mode of production that uniquely requires the saturation of life with economic logic.

\section{Social reproduction and the social factory}

This, however, does not hold up to historical or theoretical scrutiny. Marx may have argued that the real subsumption of everyday life was the logical telos of capitalism, but this does not mean 
it was not a feature of its early incarnations. For Marx, capitalism was always more than an economy and its particular relations of production. Rather, as Jason Read points out, it is a whole mode of production: "a historically variable relation between a particular production of material existence, and a particular social order, including forms of consciousness" [10]. Capitalism is also constituted by the ideologically charged superstructures of family, religion, law, media, etc., where the particular relations of the economic base are legitimated, reproduced and given the veneer of necessity. This has been the case since the inception of the capitalist mode of production.

What is missing from assertions that the social factory is novel is the necessary role within capitalist economies of the various arenas of social reproduction, such as the law, civil society infrastructures, the education system or religion. The most crucial sites for reproductive activity, though, are the family and the privatised domestic sphere. These are the pivotal locations for the production and reproduction of the labouring body and, I would stress, the labouring self and so are vital to the maintenance of capitalism. Consequently, they are fields that have long been structured by capitalist ideals and which, in turn, have sutured individuals into that ideological framework. Domestic work thus provides a useful example of the long history of the incorporation of the immaterial, the inalienable and the subjective into capital both as cause and effect.

Silvia Federici's Caliban and the witch, which explores the cultural logics of emergent capitalism, is a useful resource for explaining this incorporation. She describes the increasing separation of work involved in the production of goods from that associated with the reproduction of the health, well-being and life of people during the period of primitive accumulation associated with the development of capitalism. In the shift to a wage relation, the unity of production and reproduction was broken. A conceptual distance emerged between that which was considered economically and socially valuable and that which reproduced individuals and the family, often manifesting as the physical distance between the home and the organised, industrial workplace. This process differentiated work along gendered lines. In doing so, "the economic importance of the reproduction of labor-power carried out in the home, and its function in the accumulation of capital became invisible, being mystified as a natural vocation and 'women's labor"” [11].

This division between productive and reproductive labour - ultimately between the sphere of paid work and the private world of domestic labour - was no mere side effect of capitalism though. In the same way as the expansions of colonialism allowed for the accumulation of living labour, the removal of domestic labour from regimes of compensation facilitated capitalist accumulation. If capitalism necessarily requires the production, reproduction and maintenance of effective labouring bodies because they have use-value for capital, then it requires services to generate that product. Domestic labour is one of those necessary services. But when it is an unpaid workforce that is reproducing the labour-power instantiated in the body and subjectivity of each worker, domestic work also becomes implicated in surplus generation. The exchangevalue of labour-power - the 'natural' price of labour - is based upon the amount necessary to reproduce that worker and, in the context of the 'family wage', the next generation of workers (Picchio, 1992; Fortunati, 1995). If the required reproductive services do not have to be secured in the marketplace and are provided for free, wages can subsequently remain low. When supplied by an unwaged housewife then, the maintenance of health, nutrition and hygiene of the labourer is effectively supplied below cost. Wageless domestic work becomes an additional source of value as it increases the relative surplus that can be generated by any individual worker.

The economic impetus for maintaining a gendered division of labour is thus clear, but this system produces, reproduces and subsequently relies on social, cultural, interpersonal and subjective alignment. The construction of the modern bourgeois family with its patriarchal centre is key here (Engels, 2010; Brown, 2013). It is the mechanism by which the male worker - head of the household, breadwinner - is freed from the necessity to undertake the work required to reproduce his own labour. Federici designates the creation of the full-time housewife in the nineteenth century, driven by the shift to more intensive, heavy industrial work that 
required "a leap in the investment made in its reproduction" [12], as the culmination of this reorganisation of labour. This intensification of the sexual division of labour, she says, inexorably linked women to reproductive and specifically domestic labour that was considered outside of accumulation and therefore remained uncompensated. This increased women's economic dependence, generating a regime of chronic poverty, allowed the use of the male wage to control women's activity, and rendered women invisible as workers. Not only were women disenfranchised, these socioeconomic conditions also placed the woman's labour and her body as a reward for the working man, used to reduce the effects of alienation and exploitation found in his labour, thereby pacifying the workforce. Women, men and their social and interpersonal relations were fundamentally remade in these economic processes.

The significance of domestic work to capital is tacitly recognised in the widespread disciplining of women into appropriate attitudes towards the kinds of labour that would produce workers suitable for the needs of capitalism. Barbara Ehrenreich and Deirdre English (2005) document at least two centuries of shifting advice about better domestic management and deportment offered to women in popular culture, specific etiquette literature and in the education sector in the form of domestic science programmes. Not only were women's subjectivities shaped by these texts, by extension so were the subjectivities of those in their care. A particular kind of woman was produced in the absorption of middle-class virtues, appropriate household management processes and/or physical and sexual comportment. This regulated woman was also able to become "a repressive figure, disciplinarian of all the members of the family, ideologically and psychologically" whose role it was to "discipline the children who will be workers tomorrow and on the other hand discipline the husband to work today" [13].

The "unique process of social degradation" that has made women's work "invisible" is as fundamental to capitalist accumulation as the development of workers free to sell their labour power [14]. It also constitutes a powerful form of social engineering, producing a set of social and interpersonal relations, and ultimately individual subjectivities, fundamentally marked by the dictates of capital. Federici's study thus reveals that the regulation of a social factory and the incorporation of 'the soul' (as Berardi would have it) have been fundamental to capitalism from the outset.

\section{Women in the Irish Free State's Social Factory}

As a specific example of this longer history of social engineering under capitalism, I want to explore the politics of women's labour in a particular historical period of my adopted country, Ireland. This is the period of the Irish Free State, between 1922, when independence from U.K. rule was achieved, and 1937, when the Constitution that founded the Irish republic came into effect. During this era, various kinds of legislation were debated or enacted that sought to reduce the expanded public and political role extended to women during the struggle for independence - for example, the 1927 Juries Act that attempted to remove women from jury service; the 1925 ban on divorce; and various policies limiting married women's work in the civil service. The heteropatriarchal family and women's domesticity were given primacy in national discourse through this time, culminating in the Constitution in which the "State recognises the Family as the natural primary and fundamental unit group of Society" [15]. The document also asserts that "the State recognises that by her life within the home, woman gives to the State a support without which the common good cannot be achieved" [16].

But legislation developed during the Irish Free State not only exemplified materialised misogyny. Rather, it emerged from a nexus of ideological and economic priorities. In its first decade, the Irish economy was very weak. The country's agricultural economic base relied on unprotected beef exports to the U.K. with little development of domestic manufacturing or an industrial export sector; based on a trickle-down economic logic, domestic protections supported large landowning farmers and graziers, further consolidating ownership of agricultural real estate and land use; demand for agricultural labour continued the decline already precipitated by 
changes in the technological, industrial and agricultural landscape in the late nineteenth century, including the Famine; the local civil service remained small even as various public functions returned to domestic control; and there were continuing high levels of emigration, limiting growth in domestic markets, and significant internal migration to cities that increased urban poverty (Daly, 1995; Kennedy, et al., 1988; McCabe, 2011; Ó Gráda, 1997).

Generating employment was thus a key policy concern of the Irish Free State. Its central focus was on getting men - and specifically men - back to work, discriminating in favour of veterans of World War I, the War of Independence and the Civil War. As Mary E. Daly summarises, while there was no formal economic agenda to exclude women from the workplace, this economic policy meant that in the Irish Free State "men had a higher participation rate, access to many low-paid labouring jobs which were closed to women, and greater prospects of controlling farms or other family businesses by middle age. They dominated skilled trades and apprenticeships as they did in other countries" [17]. This designation of men as primary breadwinners worked in conjunction with the divorce ban to bind women economically to the patriarchal family. This aligned with the growing need to secure and assure paternity for purposes of inheritance for the growing rural bourgeoisie, as well as anxiety over the costs to the state for the care of illegitimate children and their mothers (Inglis, 1997; Luddy, 2011), to place a high economic value on traditional domesticity. Capitalism's gendered division of labour that Federici describes, including its costs for women's economic and social independence, was mobilised and further entrenched in this economic context.

Like the Victorian domesticity Federici also discusses, this was not only a material economic phenomenon: it was also discursive and ideological. Women taking up sanctioned roles in the household economy aligned with the cultural agenda of the post-colonial Irish State as they were able to perform their role as 'cultural transmitters' of traditional 'Irishness'. This identity was conceived as distinct from that of the U.K. because of its emphasis on a conservative Catholic morality resembling Victorian bourgeois sensibilities. Women's domesticity was thus an important part of the wider post-colonial cultural agenda. Consequently, it was asserted by government officials that "the primary role of women was marriage and motherhood, that woman's place was in the home, tending to the needs of their husbands, raising their children" [18]. In the intersection of these cultural and economic logics, the Constitutional clauses that privilege heterosexual marriage and women's domesticity make sense, as do the range of policies limiting women's roles in the public sphere. It also reinforced a very narrow definition of acceptable femininity.

\section{Magdalene Laundries as social factory}

The aggressive re-inscription of the gendered division of labour formally articulated in such legislation had significant impact on women's working lives. In 1926, Ireland had one of the lowest rates of female participation in paid employment outside of the family in Western Europe (Daly, 1995). However, that this figure also included a significant number of single women and that it was generated before the marriage bar was in place suggests that there was more than specific labour or economic policies that were keeping women out of work. There was also a broad range of social and cultural infrastructures underpinning and maintaining the gendered division of labour integral to the economy of the Irish Free State. It is in these formal and informal institutions that we can see the remaking and reinforcing of subjectivity in the service of capital as immaterial and inalienable goods such as embodied selfhood, interpersonal relationships and culture become indivisible from the state's economic imperatives. In these institutions, we see the egregious machinery of a complex social factory.

In the Irish Free State, the gendered division of labour was enforced by social, cultural and carceral means, many of which specifically targeted women's sexuality and, in particular, the maternal body. As Una Crowley and Rob Kitchin (2008; see also Luddy, 2001) describe, in this period a moral landscape was articulated in which the sexual conduct of individuals was 
inundated with regulations. They point to the intersection of proscriptive measures such as censorship and bans on contraception and dances, and prescriptive strategies such as Church sermons, elite discourses and other moralising cultural products to assert and police the illegitimacy of desire outside of procreative sex within heteropatriarchal marriage structures. Transgressions of appropriate femininity, such as unsanctioned pregnancy, perceived promiscuity or deviance, engaging in prostitution, or other expressions of unauthorised sexuality, were policed by voluntary and, more latterly, involuntary incarceration in institutions such as the County Homes, Mothers and Babies Homes and, the focus of this study, Magdalene Laundries.

While having a longer history and not necessarily being an Irish or Catholic phenomenon, Magdalene Laundries were given a particular impetus and punitive function in the nascent Irish republic, effectively taking on various state roles in lieu of adequate social services. They were residential facilities and commercial laundries populated by women considered 'fallen' through contravening gendered norms of behaviour or deemed 'unproductive' due to poverty, disability or illegitimacy; they were homes for those who "presented a challenge to the economic stability of men newly converted to the benefits of capital accumulation" [19]. Women were often placed in these asylums by their own family or by religious organisations, or they were incarcerated by the state in order to undergo 'rehabilitation,' which included moral reflection and nominal training in domestic duties. As described by one inmate, the routine was "laundry and prayer, laundry and prayer" [20].

The material economic logic of this incarceration and disciplining is clear. Having contravened the regulations of the middle-class "stem-family system" [21] that managed familial property relations, inmates were to be remade as economic subjects appropriate for the gendered division of labour of the Irish Free State and for their own disciplining duties within that. Many women left the Laundries to take up positions doing various forms of domestic, service or care work in private homes or for church run state services. The link between women's sexuality, identity and capital accumulation is further evident in the fact that these women typically worked unpaid, sometimes for years, in these commercial laundries, many of which were sustained by state service contracts. They also laboured without adequate labour rights for, as registered charities, the Laundries were not called upon to conform to state legislation in relation to the minimum wage (Department of Justice and Equality, Ireland, 2014).

Women who escaped these institutions were often returned by family or gardai (Irish police), demonstrating yet again the collusion between state and Church in the policing of women's bodies. More importantly, this also demonstrates the diffusion of patriarchal economic logics throughout society and the widespread internalisation of their associated bourgeois morality. Magdalene Laundries were part of the local community in which they were located: "They were founded in response to local conditions and demands for reform; and the success with which funds were raised and laundry orders received, reveals a system both supported and approved" [22]. That it was women who were the more ardent advocates and enforcers of this regime of bio-power (Crowley and Kitchin, 2008; Finnegan, 2001) speaks most eloquently of the successful harnessing of subjectivity and sexuality to the agenda of the nascent capitalist Irish state.

The "thematic of sin" [를 through which sexuality was deployed as a form of bio-power in the Irish Free State described "a dense spatialised grid of discipline, reform and self-regulation" [24], working punitively and positively to produce virtuous, chaste, domestically oriented, 'decent' women. The spread of Catholic thinking through the cultural fabric also "facilitated the creation of an unpaid workforce that underpinned Irish capitalism" [25]. The founding socioeconomic logics of the Irish state thus generated a landscape which de-legitimated women's economic and social independence, and in particular their bodily autonomy, as part of a wider economic agenda. This logic became normalised as part of being a woman and part of everyday female experience and in turn worked to support that economic system by ensuring domesticity and thus the reproduction of the labour force below cost. 
There is much to critique in the gendering of labour in the Irish Free State and in the monstrosity of the Magdalene system. What is important for this paper, though, is that they clearly demonstrate the real subsumption of life — the disciplining of body and soul - into capitalism. They demonstrate that immaterial labour, such as work on the self or the disciplining of others, was integral to the particular capitalist economics of the Irish Free State. The inability to clearly extricate the economic from the social from the moral from the cultural from the subjective from the interpersonal in this story indicates a social factory exploiting immaterial labour in operation long before the post-Fordist transformations described by Lazzarato.

\section{Implications of the long history of the social factory}

There is more at stake in this discussion than recognition of the economic logics of the policing of women's bodies in Ireland, although this is important. The wider conclusion to draw from feminist critiques of the social factory concept and this examination of Irish women's labour histories is that subjective, immaterial and embodied experience — life — has always been intertwined with capitalism in complex ways; that the history of capitalism is the history of struggle within and against a social factory, particularly for those in subaltern groups. The real subsumption of life may, at times, have been unsuccessfully or crudely and violently implemented, but it has always been a part of capitalism's mode of accumulation. This reframing has implications for how we might engage with the concept of immaterial labour as we continue to interrogate its digital forms.

If, as argued here, the social factory is merely the conditions of capitalism, then immaterial labour, particularly the work of social reproduction, has always had a central place. There may have been an intensification of the importance placed upon immaterial activities in work practices and in the spreadsheets that determine economic value for corporations and perhaps a naturalisation that diminishes the need for (symbolic) violence to maintain discipline in relation to this dynamic. Nevertheless, this does not mean that there has recently been the introduction of an entirely new paradigm of work. Consequently, there is a demand for clear definition of what is new, if anything, about the particular ways in which immaterial labour is absorbed into and exploited within digital capitalism. We need to determine whether there is something specific about digital labour. If it is a matter of changes in the intensity, extensity or visibility of capitalism's exploitation of living labour, then we need to provide evidence of such shifts. This needs to be a first priority.

The critique presented here through the particularity of the Irish Magdalene system also connects immaterial labour to the complexity of capitalist relations already understood by feminists and experienced in the everyday life of women and all those who occupy "the interstices between normalized social categories" [26]. This places feminist, queer and race perspectives on work such as those in this volume at the forefront in attempting to understand digital labour practices. Any assessment of change in labour practices must take its measure from histories that range beyond that of white and/or masculine industrial manufacturing labour in the developed world. It must also look to work typically framed in orthodox Marxist accounts as unproductive, such as unpaid domestic labour or volunteer work, and explore similarities and differences between it and the lived work experiences of contemporary labouring subjects. Effectively, the historical and cultural specificity of contemporary labour must be clarified if we are to articulate a transformative critical politics that speaks to the exploitation of immaterial labour.

These critiques also challenge the pervasive notion that the inalienable is always somehow outside of capitalism. This is clearly demonstrated in the example of women's labour in the Irish Free State where the most immaterial and inalienable of products — the 'souls' of women were produced and reproduced in the service of a state economic goal. Accepting the productivity of these kinds of immaterial goods and the socialised labour that produces them suggests that we also need to document the ways in which passions, affects and subjectivity 
serve capitalism in their inalienable forms. It becomes important to document not only that immaterial labour serves capitalism through its commodification and monetisation, but also the various ways in which it reproduces capitalist social logics. This leads us to consider more closely models of labour, such as the Marxist feminist perspectives on domestic work I have described elsewhere (Jarrett, 2016), that illuminate not only the economic dimensions of such work, but also their interpersonal, psychological and cultural functions within capitalist accumulation. Such models seem vital if we are to understand fully work that is immaterial, cognitive, communicative or affective.

The key reason to present this critique, though, is to encourage future studies to move away from emphasising the novelty of immaterial labour and instead provide more nuanced and contextualised understandings of its relationship to capital, both in generalised overviews of the contemporary capitalist condition but also in studies of specific digital labour practices. The long history of immaterial labour's exploitation and the complexity of women's labour experiences under capitalism revealed by this exploration of Irish women's labour demands further attention to the interrelationships between economics, politics, subjectivity, gender, sexuality, embodiment and race in all work practices. It suggests that rather than the real subsumption of life being the conclusion of our research into immaterial labour, it needs to be the beginning. This allows us to move beyond a critique that laments our incorporation into capital and understand more about the forms it currently takes and therefore what might constitute effective resistance or transformative action within that context. Immaterial labour and the politics of the social factory may not be new, but we can come to new critical insights if we embrace the complexity of their long and varied histories. $\mathbf{F m}$

\author{
About the author \\ Dr. Kylie Jarrett is Senior Lecturer in Multimedia in the Department of Media Studies at \\ Maynooth University, Ireland. She is author of Feminism, labour and digital media: The digital \\ housewife (Routledge, 2016) and co-author with Ken Hillis and Michael Petit of Google and the \\ culture of search (Routledge, 2014). She has published extensively on the political economy of \\ the commercial Web, including such platforms as Facebook, YouTube and eBay. \\ E-mail: kylie [dot] jarrett [at] mu [dot] ie
}

\title{
Notes
}

1. This article is modified from a paper published in French in Poli (Jarrett, 2017) and it draws on arguments in my 2016 book Feminism, labour and digital media: The digital housewife.

2. Hardt and Negri, 2005, pp. 111-112.

3. Marazzi, 2011, p. 94.

4. Virno, 1996, p. 14.

5. Dyer-Witheford, 1999, p. 81.

6. Negri, 1989, p. 92. Emphasis added.

7. Terranova, 2013, p. 53. Emphasis added.

8. Berardi, 2009, pp. 115-116.

9. Wark, 2013, p. 74. Emphasis added.

10. Read, 2003, p. 4. 
11. Federici, 2004, pp. 74-75. See also Brown, 2013; Hartmann, 1978; Mies, 1988; Vogel, 2013, for extended discussions of the relationship between domestic labour, women's oppression and capitalism.

12. Federici, 2011, p. 62.

13. Dalla Costa and James, 1975, pp. 47-48.

14. Federici, 2004, p. 75.

15. Article 41.1.1.

16. Article 41.2.1.

17. Daly, 1995, p. 109.

18. Gialanella Valiulis, 1995, p. 122.

19. Smith, 2007, p. 28; see also O'Sullivan and O’Donnell, 2012.

20. Department of Justice and Equality, Ireland, 2014, p. 943.

21. Inglis, 1997, p. 13.

22. Finnegan, 2001, p. 46.

23. Inglis, 1997, p. 12.

24. Crowley and Kitchin, 2008, p. 367.

25. Buckley, 2016, n.p.

26. Sandoval, 2000, p. 45.

\section{References}

Franco Berardi, 2009. The soul at work: From alienation to autonomy. Translated by Francesca Cadel. Los Angeles, Calif.: Semiotext(e).

Heather Brown, 2013. Marx on gender and the family: A critical study. Chicago: Haymarket Books.

Sarah-Anne Buckley. 2016. "The Catholic cure for poverty," Jacobin (27 May), at https://www.jacobinmag.com/2016/05/catholic-church-ireland-magdalene-laundries-motherbaby-homes/, accessed 12 December 2017.

Una Crowley and Rob Kitchin, 2008. "Producing 'decent girls': Governmentality and the moral geographies of sexual conduct in Ireland (1922-37), "Gender, Place \& Culture, volume 15, number 4, pp. 355-372.

doi: https://doi.org/10.1080/09663690802155553, accessed 7 February 2018.

Mariarosa Dalla Costa and Selma James, 1975. The power of women and the subversion of the community. Third edition. Bristol: Falling Wall Press.

Mary E. Daly, 1995. "Women in the Irish Free State 1922-39: The interaction between economics and ideology," Journal of Women's History, volume 6, number 4, and volume 7, number 1, pp. 99-116.

doi: https://doi.org/10.1353/jowh.2010.0392, accessed 7 February 2018. 
Department of Justice and Equality, Ireland, 2014. "Report of the Inter-Departmental Committee to establish the facts of State involvement with the Magdalen Laundries," at http://www.justice.ie/en/JELR/Pages/MagdalenRpt2013, accessed 10 December 2017.

Nick Dyer-Witheford, 1999. Cyber-Marx: Cycles and circuits of struggle in high-technology capitalism. Urbana: University of Illinois Press.

Barbara Ehrenreich and Deirdre English, 2005. For her own good: Two centuries of the experts' advice to women. Second Anchor Books edition. New York: Anchor Books.

Friedrich Engels, 2010. The origin of the family, private property and the state. London: Penguin Classics.

Silvia Federici, 2011. "On affective labor,” In: Michael A. Peters and Ergin Bulut (editors). Cognitive capitalism, education, and digital labor. New York: Peter Lang, pp. 57-73.

Silvia Federici, 2004. Caliban and the witch. New York: Autonomedia.

Frances Finnegan, 2001. Do penance or perish: A study of Magdalen asylums in Ireland. Piltown, Co. Kilkenny: Congrave Press.

Leopoldina Fortunati, 1995. The arcane of reproduction: Housework, prostitution, labor and capital. Translated by Hilary Creek. Brooklyn, N.Y.: Autonomedia.

Maryann Gialanella Valiulis, 1995. "Power, gender and identity in the Irish Free State," Journal of Women's History, volume 6, number 4, and volume 7, number 1, pp. 117-136. doi: https://doi.org/10.1353/jowh.2010.0308, accessed 7 February 2018.

André Gorz, 2010. The immaterial: Knowledge, value and capital. Translated by Chris Turner. London: Seagull Books.

Melissa Gregg, 2011. Work's intimacy. Cambridge: Polity.

Michael Hardt and Antonio Negri, 2005. Multitude: War and democracy in the age of Empire. New York: Penguin Books.

Heidi Hartmann, 1978. "Capitalism, patriarchy, and job segregation by sex," In: Zillah R. Eisenstein (editor). Capitalist patriarchy and the case for socialist feminism. New York: Monthly Review Press, pp. 206-247.

Eva Illouz, 2007. Cold intimacies: The making of emotional capitalism. Cambridge: Polity.

Tom Inglis, 1997. "Foucault, Bourdieu and the field of Irish sexuality," Irish Journal of Sociology, volume 7, number 1, pp. 5-28. doi: https://doi.org/10.1177/079160359700700102, accessed 7 February 2018.

Kylie Jarrett, 2017. "Le travail immatériel dans l'usine sociale: Une critique féministe," PoliPolitique de l'image, numéro 13, pp. 12-25, and at https://polirevue.files.wordpress.com/2017/03/poli-13-jarrett.pdf, accessed 7 February 2018.

Kylie Jarrett, 2016. Feminism, labour and digital media: The digital housewife. New York: Routledge, Taylor \& Francis.

Kieran A. Kennedy, Thomas Giblin and Deirdre McHugh, 1988. The economic development of Ireland in the twentieth century. London: Routledge.

Maurizio Lazzarato, 1996. "Immaterial labor," In: Paolo Virno and Michael Hardt (editors). Radical thought in Italy: A potential politics. Minneapolis: University of Minnesota Press, pp. 132-146. 
Maria Luddy, 2011. “Unmarried mothers in Ireland, 1880-1973,” Women's History Review, volume 20, number 1, pp. 109-126.

doi: https://doi.org/10.1080/09612025.2011.536393, accessed 7 February 2018.

Maria Luddy, 2001. "Moral rescue and unmarried mothers in Ireland in the 1920s," Women's Studies, volume 30, number 6, pp. 797-817.

doi: https://doi.org/10.1080/00497878.2001.9979416, accessed 7 February 2018.

Christian Marazzi, 2011. Capital and affects: The politics of the language economy. Translated and with an introduction by Giuseppina Mecchia. Los Angeles, Calif.: Semiotext(e).

Conor McCabe, 2011. The sins of the father: Tracing the decisions that shaped the Irish economy. Dublin: History Press Ireland.

Maria Mies, 1988. "Social origins of the sexual division of labour," In: Maria Mies, Vernoika Bennholdt-Thomsen and Claudia von Werlhof (editors). Women: The last colony. London: Zed Books, pp. 67-95.

Antonio Negri, 1989. The politics of subversion: A manifesto for the twenty-first century. Translated by James Newell. Cambridge: Polity.

Cormac Ó Gráda, 1997. The rocky road: The Irish economy since the 1920s. Manchester: Manchester University Press.

Eoin O'Sullivan and Ian O'Donnell (editors), 2012. Coercive confinement in Ireland: Patients, prisoners and penitents. Manchester: Manchester University Press.

Antonella Picchio, 1992. Social reproduction: The political economy of the labour market. Cambridge: Cambridge University Press.

Jason Read, 2003. The micro-politics of capital: Marx and the prehistory of the present. Albany: State University of New York Press.

Nikolas Rose, 1999. Powers of freedom: Reframing political thought. Cambridge: Cambridge University Press.

Chela Sandoval, 2000. Methodology of the oppressed. Minneapolis: University of Minnesota Press.

James M. Smith, 2007. Ireland's Magdalen laundries and the nation's architecture of containment. Notre Dame, Ind.: University of Notre Dame Press.

Tiziana Terranova, 2013. "Free labor," In: Trebor Scholz (editor). Digital labor: The Internet as playground and factory. New York: Routledge, pp. 33-57.

Tiziana Terranova, 2000. "Free labor: Producing culture for the digital economy," Social Text, volume 18, number 2, pp. 33-58. doi: https://doi.org/10.1215/01642472-18-2_63-33, accessed 7 February 2018.

Mario Tronti, 1973. "Social capital," Telos, number 17, pp. 98-121. doi: https://doi.org/10.3817/0973017098, accessed 7 February 2018.

Paolo Virno, 1996. "The ambivalence of disenchantment," In: Paolo Virno and Michael Hardt (editors). Radical thought in Italy: A potential politics. Minneapolis: University of Minnesota Press, pp. 12-33.

Lise Vogel, 2013. Marxism and the oppression of women: Toward a unitary theory. Chicago: Haymarket Books. 
McKenzie Wark, 2013. "Considerations on a hacker manifesto," In: Trebor Scholz (editor). Digital labor: The Internet as playground and factory. New York: Routledge, pp. 67-75.

\section{Editorial history}

Received 22 January 2018; accepted 7 February 2018.

\section{(c) (i) (2)(2)}

This paper is licensed under a Creative Commons Attribution-NonCommercial-ShareAlike 4.0 International License.

Laundering women's history: A feminist critique of the social factory by Kylie Jarrett.

First Monday, Volume 23, Number 3 - 5 March 2018

https://firstmonday.org/ojs/index.php/fm/article/download/8280/6647

doi: http://dx.doi.org/10.5210/fm.v23i3.8280 